\title{
AGE OF THE TOKKALEHTO METAGABBRO AND ITS SIGNIFICANCE TO THE LITHOSTRATIGRAPHY OF THE EARLY PROTEROZOIC KUUSAMO SUPRACRUSTAL BELT, NORTHERN FINLAND.
}

\author{
PAUL M. EVINS and KAUKO LAAJOKI
}

EVINS, PAUL and LAAJOKI, KAUKO 2001. Age of the Tokkalehto metagabbro and its significance to the lithostratigraphy of the early Proterozoic Kuusamo supracrustal belt, northern Finland. Bulletin of the Geological Society of Finland 73, Parts 1-2, 5-15.

The c. $30-\mathrm{km}^{2}$ Tokkalehto metagabbro and associated sills and dykes intrude a large part of the western part of the early Proterozoic Kuusamo supracrustal belt in northern Finland. These rocks have previously been mapped as a metavolcanic unit, Greenstone Formation III, the type area of which occurs further east in the Kuusamo supracrustal belt. However, observations along the contacts of this unit (contact breccias, distinctive skarns and xenoliths) and within this unit (igneous layering and mafic enclaves) indicate that these rocks are intrusive.

High resolution SIMS analysis of zircon from the metagabbro at Nurkamokumpu yields a crystallization age of $2216.2 \pm 3.8 \mathrm{Ma}$. On the basis of this age and the lithological and petrographical characteristics of the metagabbro, it belongs to the c. $2.2 \mathrm{Ga}$ karjalite or gabbro-wehrlite suite, which has a wide distribution in eastern and northern Finland.

These results show that the strong aeromagnetic anomalies of the western part of the Kuusamo supracrustal belt do not represent Greenstone Formation III metavolcanics. A subdivision of the Kuusamo supracrustal belt into eastern and western halves is proposed along the Kitka Fault. Instead, these anomalies represent c. $2.2 \mathrm{Ga}$ gabbroic intrusions, which intruded metasediments of the western Kuusamo supracrustal belt.

Key words: metagabbro, intrusions, absolute age, U/Pb, magmatism, lithostratigraphy, magnetic anomalies, Proterozoic, Tokkalehto, Kuusamo, Finland

Paul Evins and Kauko Laajoki: University of Oulu, Department of Geology, P.O. Box 3000, FIN-90401 Oulu, Finland.

E-mails:pevins@babel.oulu.fi,klaajoki@sun3.oulu.fi 


\section{INTRODUCTION}

The Kuusamo supracrustal belt is one of the key areas where the early Proterozoic sedimentaryvolcanic cover of the late Archean basement of the Fennoscandian Shield can be studied. The Geological Survey of Finland has mapped the belt at the 1: 100000 scale (Silvennoinen 1973, 1982, 1989, unpublished sheets 3544 and 4611). Silvennoinen $(1972,1991)$ has outlined the stratigraphy of the eastern part of the belt whereas that of the western part has been published only on smallscale maps (Silvennoinen et al. 1992, Korsman et al. 1997).

The type area of the Kuusamo supracrustal sequence is the Rukatunturi area in the eastern part of the belt. Here the sequence is over $2500 \mathrm{~m}$ thick and is subdivided by Silvennoinen (1972) into thirteen formations including three metavolcanic units named Greenstone Formation I, II, and III. The c. 200-m thick Greenstone Formation III is usually strongly magnetic and has been used as a key unit in mapping. This formation covers a large area of the western part of the Kuusamo supracrustal belt on the small-scale maps of Silvennoinen et al. (1992) and Korsman et al. (1997). Our mapping, however, has not revealed any significant metavolcanic unit corresponding to magnetic anomalies in this area. Instead, the strong positive magnetic anomalies appear to represent a c. $30-\mathrm{km}^{2}$ large metagabbro intrusion. This metagabbro is named after Tokkalehto where it is best exposed

3600

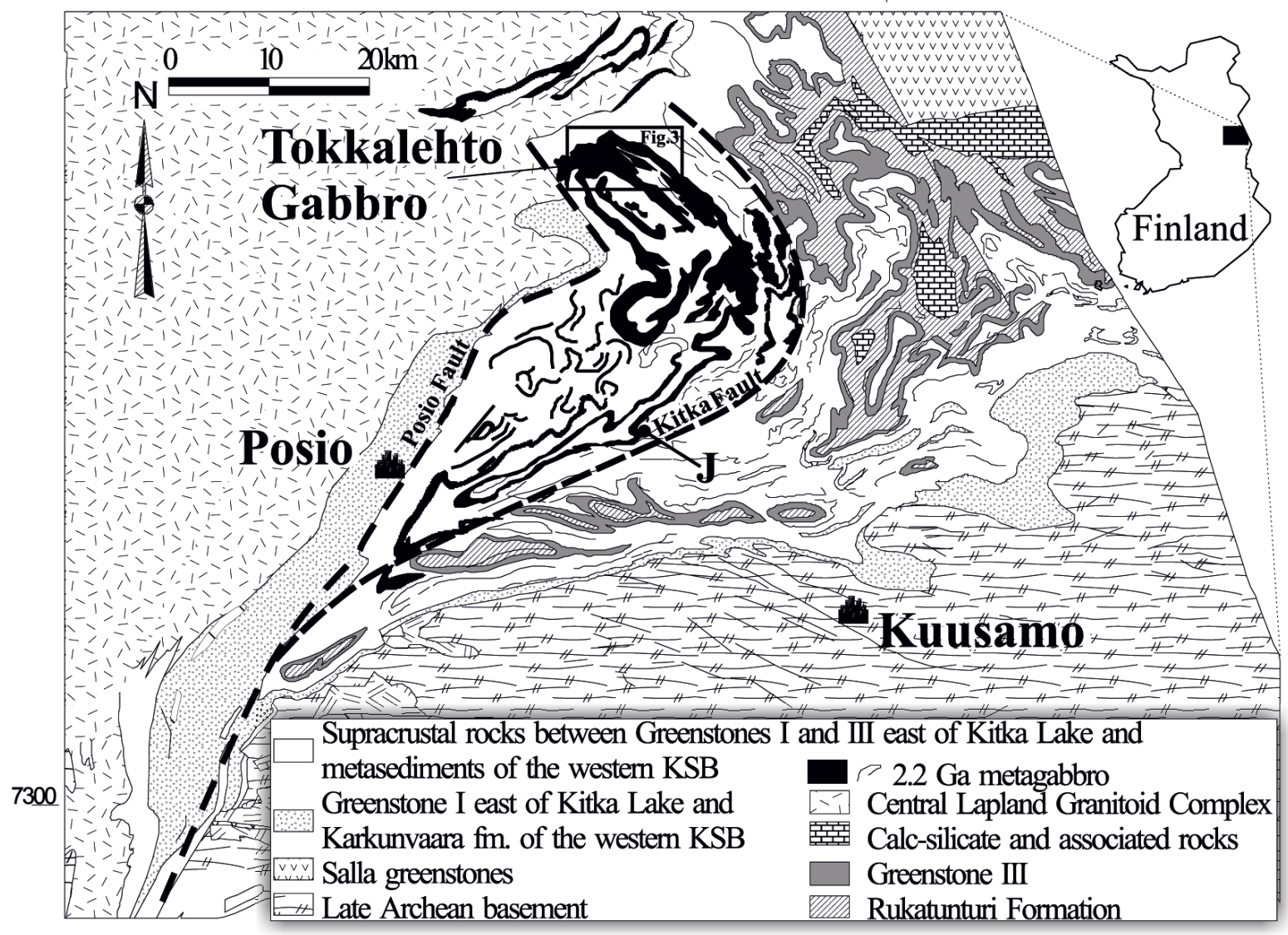

Fig. 1. Map of the Kuusamo supracrustal belt (modified from Korsman et al. 1997) and distribution of the Tokkalehto metagabbro (black). $J$ = Jäkäläniemi. Area of detailed map in Fig. 3 is framed. 
and easily accessible by a forest road.

The main purpose of this study is to describe the intrusive characteristics of the Tokkalehto metagabbro and present its age as determined at the NORDSIM laboratory in Stockholm. The significance of the Tokkalehto metagabbro to the lithostratigraphy of the Kuusamo supracrustal belt is then discussed.

\section{GEOLOGICAL SETTING}

The early Proterozoic Kuusamo supracrustal belt covers a triangular region some $2500 \mathrm{~km}^{2}$ in area in northern Finland (Fig. 1). It is bordered by the late Archean Kuhmo Basement Complex, the early Proterozoic Salla Greenstone Belt, and the early Proterozoic Central Lapland Granitoid Complex in the south, in the northeast, and in the northwest, respectively. The boundary with the Kuhmo complex is a nonconformity, the one with the Salla belt is tectonic (Manninen 1991, Ruotoistenmäki 1992, Airo 1999), and the boundary with the Central Lapland Granitoid Complex is tectonic (along the Posio Fault) and intrusive (Laajoki 1994, Kärki \& Laajoki 1995, Evins et al. 1997). The Kuusamo supracrustal belt was subjected to several phases of deformation and consequently its structure is rather complex.

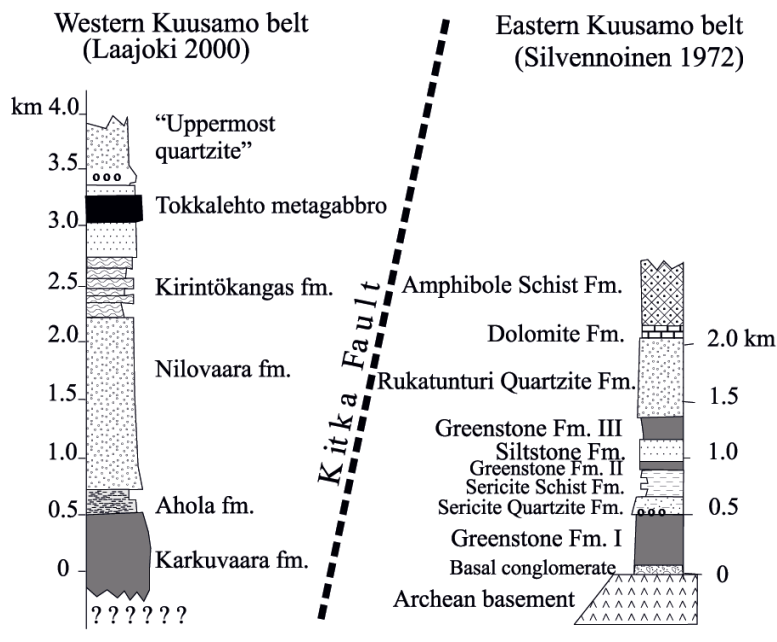

Fig. 2. Differences in lithostratigraphy between the western and eastern Kuusamo supracrustal belt.
The stratigraphy of the Kuusamo supracrustal belt is best known along its southeastern margin where the cover sequence starts with a basal breccia conglomerate (Fig. 2). The $2405 \pm 6$ Ma age (Silvennoinen 1991) of three quartz-porphyry clasts in the conglomerate gives the maximum age of the beginning of sedimentation in Kuusamo. The overlying sequence is at least $2300 \mathrm{~m}$ thick and consists of three volcanic formations (Greenstone Formation I, II and III) with intervening sedimentary units. Greenstone II and overlying siltstone formations are cut by a $2209 \pm 9$ Ma (Silvennoinen 1991) metadiabase at Jäkäläniemi on the Vasaraperä map sheet (Fig. 1). The 200-m thick Greenstone Formation III of massive, floodbasaltic metalavas is overlain by a 600 - to $800-\mathrm{m}$ thick sequence of clean quartzites with minor heteroliths of the Rukatunturi Formation. The uppermost units, the 0- to 100-m thick Dolomite Formation and the $>250-\mathrm{m}$ thick Amphibole Schist Formation, are found only in restricted areas to the north.

In Posio to the west, the stratigraphy is not easily resolved due to sparser outcrops, higher degree of metamorphism, more complex folding, and several shear zones. Laajoki (2000) has established a tentative stratigraphy for the area that differs significantly from that of the eastern Kuusamo supracrustal belt (Fig. 2). The Ahola formation consists of sillimanite facies, turbiditic metasandstones and metapelites deposited upon subaerial lavas of the Karkuvaara formation. The latter is usually correlated with Greenstone Formation I (Silvennoinen et al. 1992, Korsman et al. 1997). Quartzites of the Nilovaara formation overlay the Ahola formation. The Nilovaara quartzites are overlain by the distinctive Kirintökangas formation, which consists of alternating members of sandstone and heterolith of presumed tidal to shallow-marine origin (Laajoki 1996). This formation eventually grades upwards into arkosic and micaceous quartzites and siltstones with sillimanitegrade mica schist interbeds in the westernmost part of the area. The Tokkalehto metagabbro intrudes the upper part of this formation. The Himmerkinlahti conglomerate member described by Laajoki (2000) rests unconformably atop quartzites of the 
previous formation and grades into the siltstones and quartzites of the "Uppermost quartzite". Note that the eastern and western parts of the Kuusamo belt cannot be directly correlated lithostratigraphically with each other. They are considered as separate tectonic units.

The Tokkalehto area lies between Posio and the eastern Kuusamo supracrustal belt (Fig. 1). Silvennoinen (1992) subdivides the supracrustal sequence here into the Lapponia (lower) and Karelia supergroups. The latter includes in its lower part plateau basalts, which on the basis of the map by Silvennoinen et al. (1992) are correlated with Greenstone Formation III. Korsman et al. (1997) subdivide the sequence into a lower quartzite- arkosite-mica schist unit and upper quartzite unit separated by a metavolcanic unit (units 60,58, and 57, respectively, on their map). The geology of this metavolcanic unit (here re-interpreted as a metagabbro) is described below.

\section{GEOLOGY OF THE TOKKALEHTO METAGABBRO}

The Tokkalehto metagabbro intrudes arkose-, sericite-, fuchsite-, or ortho-quartzites and sillimanite- or garnet-muscovite-biotite schists of the western Kuusamo supracrustal belt. In the study area, the intrusive body trends northwestward,

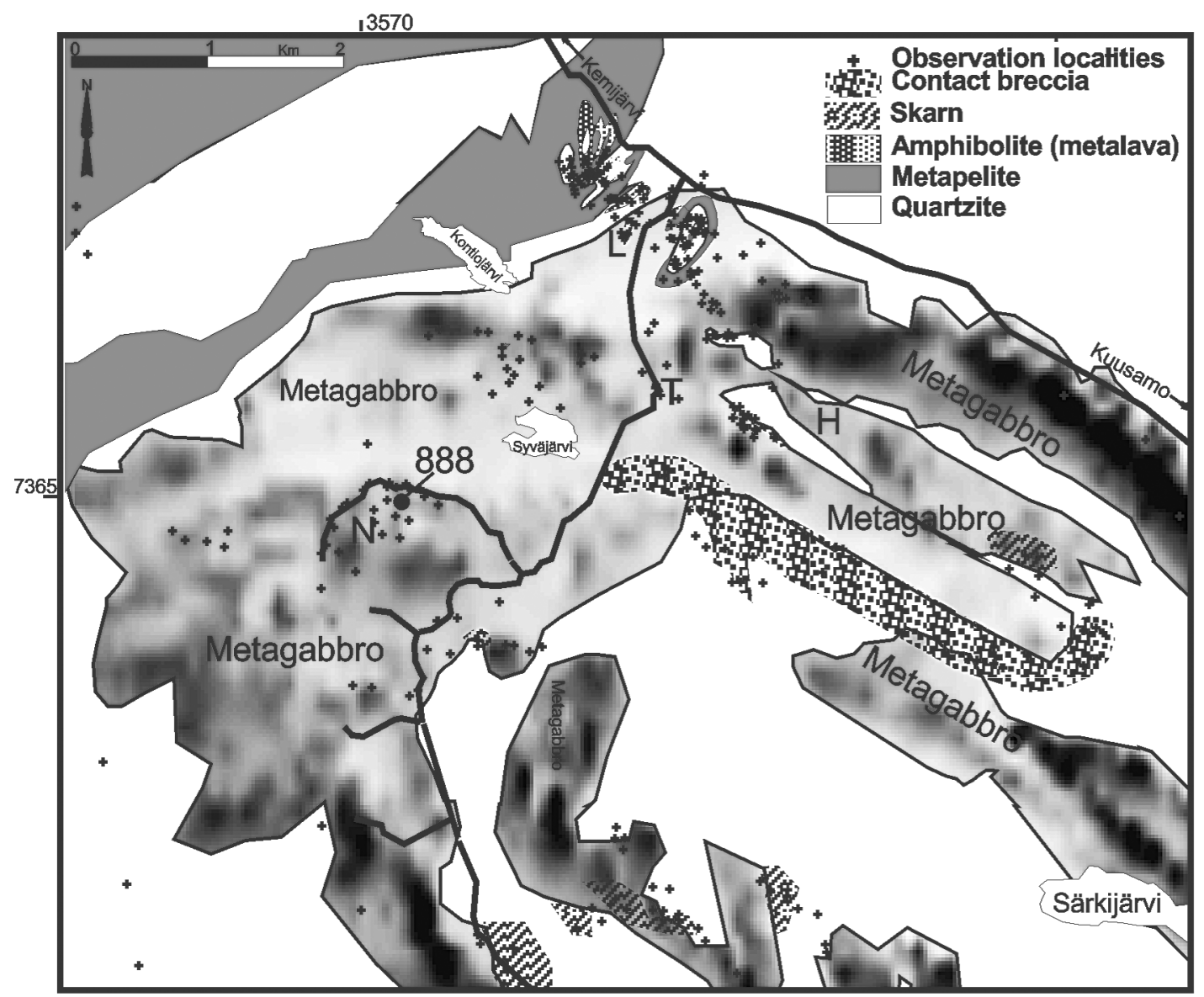

Fig. 3. Detailed map of the main part of the Tokkalehto metagabbro (shown with its aeromagnetic signatures) in the northwest with the location of sample \# 888 and observation stations. T=Tokkalehto, N=Nurkamokumpu, $L=$ Lauttalampi, $H=$ Hanhilammi. 
generally parallel to layering (composite $S_{0} / S_{1}$ ) in its host and to the structural grain of this part of the Kuusamo supracrustal belt (Fig. 3). It has been complexly folded by several phases of deformation. Along with its host sediments, it forms a large fold with a moderately southwest-dipping, northwest-trending axial plane. Numerous mylonite zones with strong southward plunging lineations are parallel to this axial plane and cut through the metagabbro. The hinge of the large fold is centered at Tokkalehto. Its northern limb follows the road to Kuusamo and southern limb follows the forest road to the southeast. In the northwestern corner of the area, near Lauttalampi, a series of northeast-trending shear zones juxtaposes high-grade garnetiferous schists and sillimanite-bearing arkosites against the Tokkalehto metagabbro and metasediments of the Kuusamo supracrustal belt. These shear zones truncate the metagabbro and older, northwest-trending fabrics in the area. A northeast-trending $\mathrm{S}_{2}$ foliation is axial planar to $F_{2}$ folds, the largest of which is represented by the deflection of the entire Tokkalehto metagabbro to a northeasterly direction south of the study area (Fig. 1). Near conformity between the metagabbro and its host's layering and internal features described below imply that it was originally intruded as a series of differentiated sills.

\section{Igneous features of the Tokkalehto metagabbro}

The Tokkalehto metagabbro usually occurs as a dark green to black, massive to foliated, mediumto coarse-grained amphibolite. Massive, coarsegrained varieties have a typical metagabbroic appearance (containing amphibole, pyroxene and plagioclase in Fig. 4a) on both the northern (Fig. 4b) and southern (Fig. 4c) limb of the intrusion. At several localities (Lauttalampi, Tokkalehto, and Nurkamokumpu) the metagabbro grades into indistinct, irregular, meter-scale regions of ultramafic rock. Some of these rocks may contain significant amounts of sulfides as evidenced by their rusty appearance. More felsic varieties are also found as c. $30-\mathrm{cm}$ thick layers of diorite to anorthosite dispersed throughout the gabbro at Nurkamokumpu. These are marked by an increase in plagioclase in the rock and occasional cumulate texture where layers can be distinguished (Fig. 4d). However, in most cases distinct layers have not formed (Fig. 4e). Instead, boundaries between felsic and mafic material are irregular. These features may have formed due to magmatic differentiation or magma mingling. Mafic enclaves (up to $5 \mathrm{~cm}$ ) composed of polycrystalline amphibole in the metagabbro at Tokkalehto and Nurkamokumpu provide further evidence of magmatic differentiation (Fig. 4f). Fine-grained layers of amphibolite and diopside-bearing granite and pegmatite veins occur within the metagabbro, usually near its contact with the host rock. Volcanic features, such as amygdules and lava pillows, have not been observed anywhere in the Tokkalehto metagabbro. All of the textures described above within the Tokkalehto amphibolite demonstrate that the rock was originally a mafic magma intruded at some depth below the surface.

\section{Contact relationships}

Due to the sill-like geometry of the Tokkalehto metagabbro intrusion, cross cutting contacts are shallow and rarely seen in outcrop (Fig. 4c), however, the intrusion isolates large blocks of the surrounding country rock (described below). Instead, contacts between the metagabbro and its metasedimentary host are marked by three types of contact zones. The most common type of contact zone occurs where metagabbro intrudes sericite quartzite causing the growth of calc-silicate minerals, such as diopside, predominantly in the quartzite. These calc-silicate skarns are found throughout the area within 200 meters of the contact. When the metagabbro intrudes less silty metasediments such as meta-arkose and orthoquartzite, albitization occurs in the quartzite. At these contacts both the metagabbro and quartzite are strongly disrupted resulting in a contact breccia. The third type of contact zone is almost completely exposed along a 200meter transect across the northwestern boundary of the metagabbro along the Nurkamokumpu Road. Here the metagabbro intrudes a garnet-biotite me- 

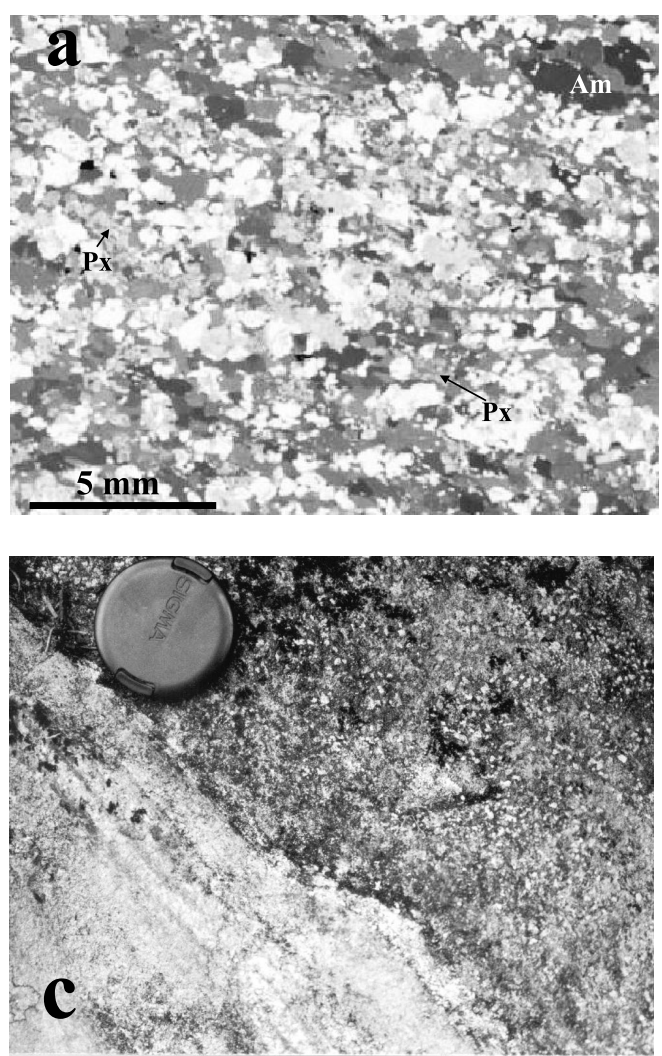
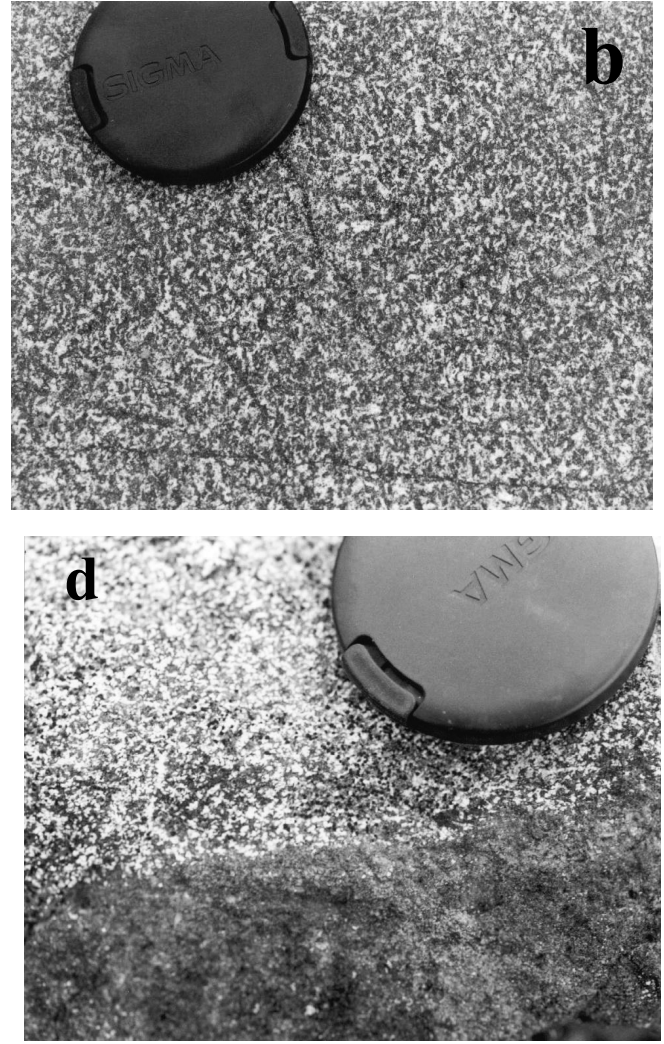
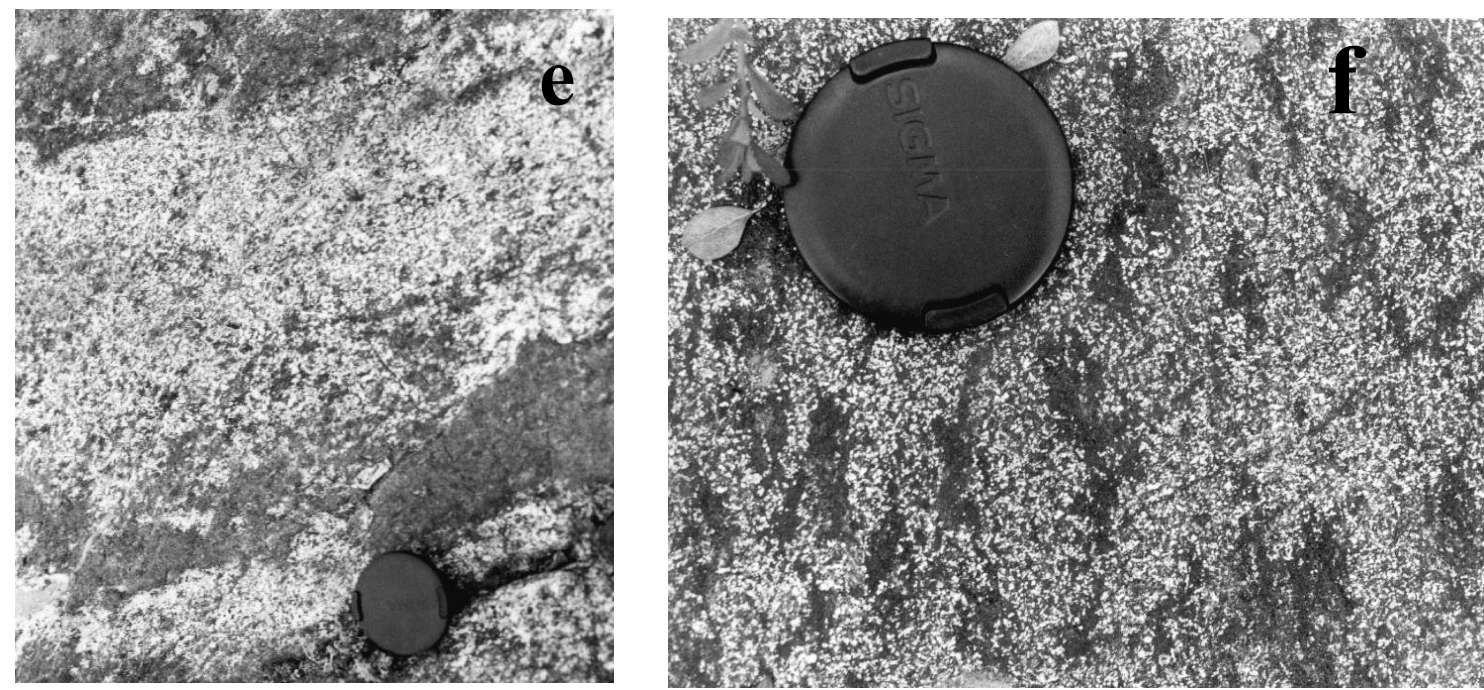

Fig. 4. Igneous features of the Tokkalehto metagabbro. a) thin section of metagabbro sampled for U-Pb analysis; b) typical appearance on the northern limb, Station \# 840; c) typical appearance on the southern limb where the metagabbro (top right) truncates layering in sericite quartzite (bottom left) at a shallow angle, Station \# 784; d) cumulate layering at Nurkamokumpu, Station \# 896; e) irregular boundary showing incomplete magmatic differentiation at Nurkamokumpu, Station \# 899; f) mafic enclaves of polycrystalline amphibole in the metagabbro at Tokkalehto, Station \# 844. Lens cap diameter is $6.5 \mathrm{~cm}$. 

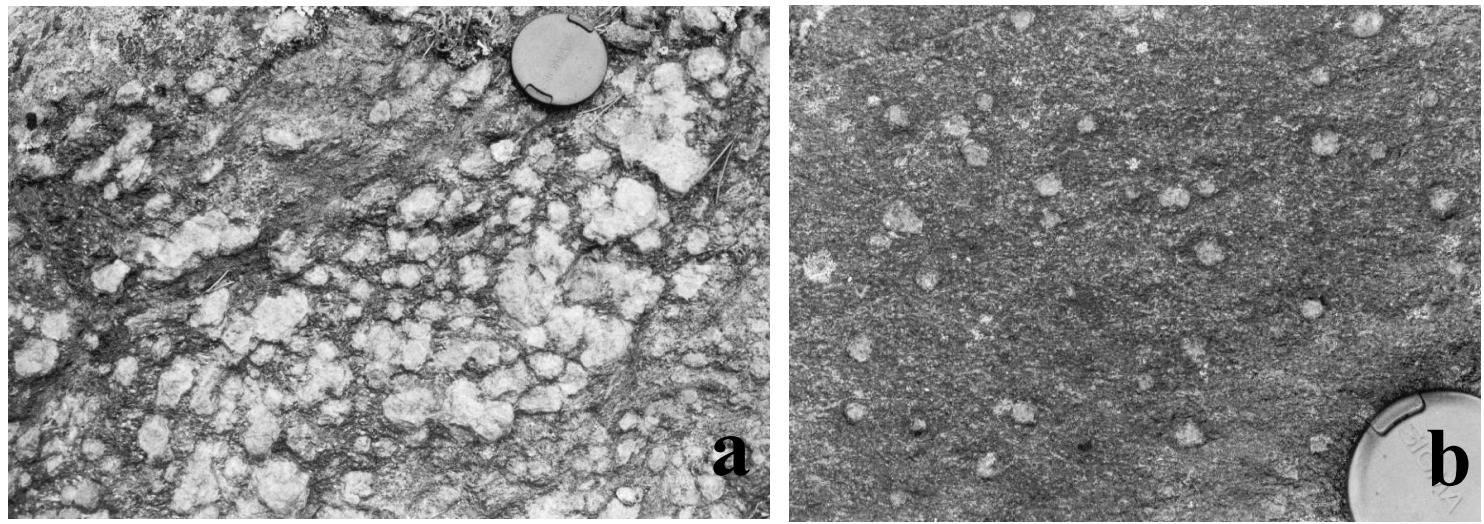

Fig. 5. Characteristics of the contact between the metagabbro and surrounding metapelites. a) sulfide-bearing garnet-gedrite skarn, Station \# 752 (garnets appear light grey); b) metagabbro with garnets from a ghost of a metapelite xenolith, Station \# 794. Lens cap diameter is $6.5 \mathrm{~cm}$.

tapelite from a strongly deformed supracrustal package that includes arkosite with pelite interbeds, sillimanite-biotite metapelite with in situ granitic melt veins, calc-silicate gneisses, and medium-grained metavolcanic amphibolite with calc-silicate layers. Two hundred meters from the metagabbro, amphibole appears in the metapelite. Garnet clusters (approximately $2 \mathrm{~cm}$ ) begin to form in the metapelite and grow larger as one approaches the metagabbro. The metapelite then grades into a c. 100-meter wide zone of sulfide-bearing garnet-gedrite skarn with large (up to $20 \mathrm{~cm}$ ) garnet clusters (Fig. 5a). Once inside the metagabbro, several 2-meter wide metapelite xenoliths, composed mostly of amphibole, garnet and biotite, have been assimilated by the metagabbro. Further away from the contact, relict ghosts of the metapelite xenoliths are represented by vague, irregular regions of $\mathrm{cm}$-sized garnets and amphibole clusters in the metagabbro (Fig. 5b). These garnets and clusters eventually disappear into pure metagabbro at $>150$ meters from the contact.

Several blocks of the metasedimentary wall rock are found within the Tokkalehto metagabbro. Of particular interest are the Hanhilammi, Tokkalehto, and Lauttalampi inclusions (Fig. 3). The 1000 x 300-meter, northwest-trending Hanhilammi inclusion consists of fuchsite quartzite, sericite quartzite, orthoquartzite, sillimanite rod arkosite, metapsammite, and biotite-muscovite metapelite. Garnet-gedrite skarn is found along parts of its contact with the metagabbro. The 100 x 50- meter, northwest-trending Tokkalehto inclusion is composed of fuchsite quartzite that has been strongly albitized and brecciated almost beyond recognition. The $700 \times 300$-meter, northeast-trending Lauttalampi inclusion is cored by quartzite surrounded by sillimanite-bearing metapelite. The quartzite contains a $1-\mathrm{m}$ wide sulfide vein. Due to lithological similarities between the xenoliths and the nearby metasedimentary host rock to the metagabbro, we interpret these inclusions as nearly in situ xenoliths.

\section{U-PB GEOCHRONOLOGY}

\section{Sample}

The dated sample is a lineated amphibolite from a recently blasted ditch along the Nurkamokumpu Road (X=7365.03, Y=3570.50 in the Finnish Uniform Coordinate System) near the center of the intrusion. It is representative of the relatively homogenous, massive, medium-grained amphibolite that makes up the majority of the intrusion. It is composed of amphibole and often sericitized plagioclase with minor, relic pyroxene and quartz (Fig. 4a). Titanite is a common accessory mineral in the rock. Amphibole and polycrystalline regions of plagioclase define a lineation in the sample. The rock sample was large $(\sim 10 \mathrm{~kg})$ and a fair amount of zircon was recovered. 


\section{Methodology}

$\mathrm{U}-\mathrm{Pb}$ isotopic measurements were conducted at the NORDSIM Laboratory for Isotope Geology at the Swedish Museum of Natural History in Stockholm. The rock sample was crushed with a jawcrusher and pulverized with a disk mill at the University of Oulu. Zircon grains were separated from the resulting rock powder by heavy mineral enrichment on a Wilfley table and subsequent magnetic separation on a Frantz isodynamic separator and density separation using tetrabromethane and di-iodinemethane at the Geological Museum in Oslo. The most transparent zircons with the least fractures and inclusions under binocular microscope were chosen for analyses. These were then mounted in epoxy with the 91500 zircon standard (Weidenbeck et al. 1995), and ground and polished with progressively finer diamond paste. Imaging the zircon under backscatter electron and cathodoluminescence (CL) aided in identifying possible cores, overgrowths, and unwanted fractures. These images were used for the final selection of spot analyses. Spots with a diameter of 30 $\mu \mathrm{m}$ where analyzed with a Cameca IMS 1270 high mass-resolution, high-sensitivity ion-microprobe at the NORDSIM Laboratory following the analytical procedure of Whitehouse et al. (1999). Data reduction was performed by Joakim Mansfeld at the NORDSIM Laboratory using a modified Excel spreadsheet (Whitehouse et al. 1997, 1999) and Isoplot/Ex by Ludwig (1998). Common Pb corrections were made assuming Stacey and Kramers' (1975) terrestrial $\mathrm{Pb}$ composition. Isotopic data are presented in Table 1.
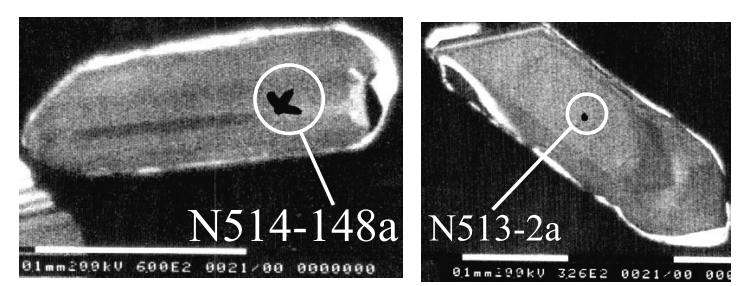

Fig. 6. Cathodoluminesence images of typical sector (left) and zoned (right) zircon from sample \# 888. Numbers refer to location of spot and number of ion-microprobe analysis in Table 1. White bar is $0.1 \mathrm{~mm}$ long.

\section{Results and interpretation}

Nearly all zircons from the sample are large and prismatic (c. $200 \mu \mathrm{m}$ long, $70 \mu \mathrm{m}$ wide). None were identified in thin section. All are remarkably transparent under plane light and display oscillatory or sector zoning under CL; typical of magmatic growth (Pidgeon 1992) (Fig. 6). No cores or overgrowths were visible. Analyses show a homogenous zircon population with one extremely discordant outlier, together showing an upper intercept age of $2250 \pm 54 \mathrm{Ma}$. Exclusion of the discordant point (analysis N514-145a in Table 1) yields a group of 9 concordant analyses. The resulting zircon age, calculated according to Ludwig (1998), is $2216.2 \pm 3.8$ Ma with a MSWD of 1.6 (Fig. 7). A weighted average of the 9 concordant ${ }^{207} \mathrm{~Pb} /{ }^{206} \mathrm{~Pb}$-ages yields an age of $2217.6 \pm 7.4$ Ma with a MSWD of 1.8 at the $95 \%$ confidence level (Fig. 7). The two ages are the same within error. In view of the homogenous nature of the analyzed zircon material (excluding the extremely discordant analysis) the upper concordia age of

Table 1. Ion-microprobe (NORDSIM) zircon data for sample \# 888. Errors shown for ${ }^{207} \mathrm{~Pb} /{ }^{206} \mathrm{~Pb}$ ratios are the greater of counting vs. observed errors. Errors in Pb/U include a generally dominant factor propagated from the standard measurements.

\begin{tabular}{|c|c|c|c|c|c|c|c|c|c|c|c|c|c|c|c|c|c|c|c|}
\hline \multirow[t]{2}{*}{ Spot \# } & \multirow{2}{*}{$\begin{array}{c}{[\mathrm{U}]} \\
\mathrm{ppm}\end{array}$} & \multirow{2}{*}{$\begin{array}{l}\text { [Th] } \\
\text { ppm }\end{array}$} & \multirow{2}{*}{$\begin{array}{l}{[\mathrm{Pb}]} \\
\mathrm{ppm}\end{array}$} & \multirow{2}{*}{$\begin{array}{l}\mathrm{Th} / \mathrm{U} \\
\text { meas }\end{array}$} & \multirow{2}{*}{${ }^{206} \frac{\mathrm{Pb}}{\mathrm{Pb}}$} & \multirow[t]{2}{*}{$\pm \sigma \%$} & \multirow{2}{*}{${ }^{207} \underline{\mathrm{Pb}}$} & \multirow[t]{2}{*}{$\pm \sigma \%$} & \multirow{2}{*}{${ }^{206} \underline{\mathrm{Pb}}$} & \multirow[t]{2}{*}{$\pm \sigma \%$} & \multirow{2}{*}{$\begin{array}{l}{ }^{206} \mathrm{~Pb} \\
\text { meas }\end{array}$} & \multicolumn{8}{|c|}{ Apparent Ages } \\
\hline & & & & & & & & & & & & ${ }^{206} \frac{\mathrm{Pb}}{\mathrm{Pb}}$ & $\pm \sigma$ & ${ }^{207} \frac{\mathrm{Pb}}{{ }^{23} \mathrm{U}}$ & $\pm \sigma$ & ${ }^{206} \mathrm{~Pb}$ & $\pm \sigma$ & ${ }^{208} \frac{\mathrm{Pb}}{\mathrm{Th}}$ & $\pm \sigma$ \\
\hline N514-145a & 67 & 130 & 34 & 1.9 & 0.1094 & 0.51 & 4.607 & 2.89 & 0.3053 & 2.84 & 24600 & 1790 & 9.3 & 1750 & 24.4 & 1717 & 43.0 & 1733 & 61.6 \\
\hline N514-148a & 102 & 98 & 57 & 1.0 & 0.1383 & 0.34 & 7.624 & 2.86 & 0.3999 & 2.83 & 21400 & 2206 & 5.9 & 2188 & 26.0 & 2168 & 52.4 & 2103 & 72.4 \\
\hline N514-163a & 91 & 58 & 48 & 0.6 & 0.1383 & 0.36 & 7.640 & 2.86 & 0.4005 & 2.84 & 50600 & 2207 & 6.3 & 2190 & 26.0 & 2172 & 52.5 & 2072 & 79.3 \\
\hline N514-151a & 101 & 73 & 55 & 0.7 & 0.1388 & 0.39 & 7.838 & 2.87 & 0.4095 & 2.84 & 6960 & 2213 & 6.7 & 2213 & 26.2 & 2213 & 53.5 & 2155 & 74.1 \\
\hline N513-8a & 80 & 62 & 45 & 0.8 & 0.1393 & 0.45 & 7.908 & 2.87 & 0.4119 & 2.84 & 52600 & 2218 & 7.7 & 2221 & 26.2 & 2223 & 53.6 & 2234 & 78.6 \\
\hline N514-160a & 92 & 78 & 49 & 0.9 & 0.1396 & 0.40 & 7.586 & 2.86 & 0.3941 & 2.83 & 3600 & 2222 & 6.9 & 2183 & 26.0 & 2142 & 51.9 & 2011 & 70.0 \\
\hline N513-2a & 140 & 112 & 76 & 0.8 & 0.1396 & 0.46 & 7.689 & 2.87 & 0.3994 & 2.84 & 33100 & 2222 & 8.0 & 2195 & 26.2 & 2166 & 52.4 & 2094 & 76.8 \\
\hline N514-150a & 69 & 50 & 38 & 0.7 & 0.1398 & 0.46 & 8.078 & 2.88 & 0.4192 & 2.84 & 24400 & 2224 & 7.9 & 2240 & 26.3 & 2257 & 54.3 & 2206 & 77.8 \\
\hline N514-156a & 55 & 29 & 29 & 0.5 & 0.1401 & 0.49 & 7.897 & 2.88 & 0.4087 & 2.84 & 72600 & 2229 & 8.4 & 2219 & 26.3 & 2209 & 53.3 & 2150 & 75.0 \\
\hline N513-10a & 76 & 40 & 41 & 0.5 & 0.1404 & 0.41 & 8.022 & 2.87 & 0.4145 & 2.84 & 58800 & 2232 & 7.1 & 2234 & 26.2 & 2235 & 53.8 & 2348 & 84.1 \\
\hline
\end{tabular}


$2216.2 \pm 3.8 \mathrm{Ma}$ is interpreted to represent the crystallization age of the Tokkalehto metagabbro.

\section{LITHOSTRATIGRAPHIC CONSEQUENCES}

The contact relationships between the Tokkalehto metagabbro and its surroundings as well as magmatic features within the intrusion described above indicate that the mafic rocks in the western Kuusamo supracrustal belt around Tokkalehto are intrusive. Consequently, these rocks cannot be correlated with Greenstone Formation III in the Rukatunturi type locality where Silvennoinen (1972, 1991) describes it as clearly volcanic with abundant amygdules and other volcanic features. The only similarity between the Tokkalehto metagabbro and Greenstone Formation III is their high aeromagnetic signatures.

The $2216 \pm 3.8 \mathrm{Ma}$ age of the Tokkalehto metagabbro is within error of the $2209 \pm 9$ Ma age (Silvennoinen 1991) reported for a metadiabase directly adjacent to the southern continuance of the Tokkalehto metagabbro (previously shown as Greenstone Formation III) at Jäkäläniemi to the south of the Tokkalehto area (Fig. 1). Their equal age and spatial continuity imply that they are part of the same intrusive body. The Tokkalehto metagabbro may, however, represent a hypabyssal facies of the Greenstone Formation III. Rocks that are undoubtedly volcanic and part of Greenstone Formation III seem to be restricted to the area east of Kitka Lake (Fig. 1).

Because of the absence of Greenstone Formation III and other substantial differences in stratigraphy (Fig. 2), we propose that a major tectonic boundary, the Kitka Fault, lies along Kitka Lake (Fig. 1). West of the Kitka Fault, positive aeromagnetic anomalies do not represent Greenstone III and therefore cannot be used as stratigraphic markers. This implies that the metasediments found in the center of the Tokkalehto metagabbro may not be part of the younger Rukatunturi Formation as represented on maps by Silvennoinen et al. (1992) and Korsman et al. (1997), but more likely represent older strata, possibly of Silvennoinen's (1972) Sericite Quartzite Formation.
Observations of major lithological and sequential discrepancies between the sediments in this area and those of the Rukatunturi Formation support this conclusion and will be discussed in a later paper. The elimination of the Rukatunturi and Greenstone III Formations from the area west of the suggested Kitka Fault implies that the Kuusamo supracrustal belt has been split into an eastern half with the complete stratigraphy described by Silvennoinen $(1972,1981)$ and a western half that may be correlative either to Silvennoinen's (1972) early Proterozoic Sericite Quartzite and Greenstone I Formations or to the Archean Central Puolanka Group (Kontinen et al. 1995) to the south. Parts of the Kuusamo supracrustal belt north of the Tokkalehto area have not been mapped in detail, and it is possible that some of the metavolcanic units corresponding to positive magnetic anomalies outlined on small-scale maps (Silvennoinen et al. 1992, Korsman et al. 1997) west and southwest of the Salla Belt represent the 2.2 Ga metagabbro suite called karjalites (Vuollo $\&$ Piirainen 1992) or the gabbro-wehrlite association (Hanski 1986) that are distributed throughout eastern and northern Finland (Vuollo 1994 and references therein). The authors emphasize that

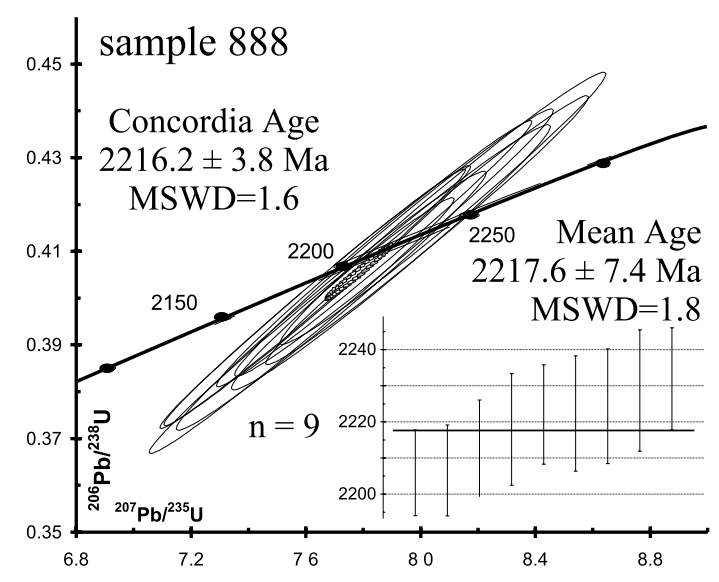

Fig. 7. U-Pb concordia and weighted mean diagrams of zircon data for sample \# 888. Error ellipses represent $1 \sigma$ on the concordia age diagram. In the lower right of this diagram is the weighted mean of ${ }^{207} \mathrm{~Pb} /$ ${ }^{206} \mathrm{~Pb}$-ages with $2 \sigma$ error bars. 
these magnetic anomalies should not be used as stratigraphic markers.

\section{CONCLUSIONS}

Aeromagnetic anomalies in the western part of the Kuusamo supracrustal belt previously represented as metavolcanics of Greenstone Formation III are, instead, differentiated gabbroic intrusions, the largest of which is the Tokkalehto metagabbro. These intrusions crystallized at 2216.2 $\pm 3.8 \mathrm{Ma}$. On the basis of its age and lithological characteristics, the Tokkalehto metagabbro belongs to the c. 2.2. Ga karjalite or gabbro-wehrlite mafic suite found dispersed throughout eastern and northern Finland.

\section{ACKNOWLEDGMENTS. Our deepest gratitude} goes out to Niina Ahtonen who carried out some of the analyses at NORDSIM. Joakim Mansfeld performed the data reduction. Torbjörn Sunde mounted the zircon and prepared the epoxy puck for analysis. His help with all of the analytical devices at the NORDSIM laboratory was much appreciated. Comments from Jouni Vuollo, Torbjörn Skiöld, Yrjö Kähkönen and Martin Whitehouse were welcome to the manuscript. This study was financially supported by the Academy of Finland and the Thule Institute, University of Oulu. NORDSIM contribution \# 49.

\section{REFERENCES}

Airo, M-L. 1999. Aeromagnetic and petrophysical investigations applied to tectonic analysis in the northern Fennoscandian Shield: interpretation of the geotectonic evolution of SE Finnish Lapland. Geological Survey of Finland, Report of Investigation 145. 51 p.

Evins, P., Laajoki, K. \& Ahtonen, N. 1997. Preliminary observations of the eastern part of the Kemijärvi complex, northern Finland. Res Terrae, Ser. A, 13, 66-70.

Hanski, E. 1986. The gabbro-wehrlite association in the eastern part of the Baltic Shield. In: Friedrich, G. \& Genkin, A.D. (eds.) Geology and Metallogeny of Copper Deposits. Berlin: Springer-Verlag, 151-170.

Kärki, A. \& Laajoki, K. 1995. An interlinked system of folds and ductile shear zones - late stage Svecokarelian deformation in the central Fennoscandian Shield, Fin- land. Journal of Structural Geology 17, 1233-1248.

Kontinen, A., Huhma, H. \& Laajoki, K. 1995. Sm/Nd isotope data on the Central Puolanka Group, Kainuu Schist Belt, Finland; constraints for provenance and age of deposition. In: Kohonen, T. \& Lindberg, B. (eds.) The 22nd Nordic Geological Winter Meeting, Turku - Åbo, 8-11 January 1995. Abstracts, p. 95.

Korsman, K., Koistinen, T., Kohonen, J., Wennerström, M., Ekdahl, E., Honkamo, M., Idman, H., \& Pekkala, Y. (eds.) 1997. Bedrock map of Finland 1: 1000 000. Geological Survey of Finland, Espoo.

Laajoki, K. 1994. Structural and stratigraphic relationship between the early Proterozoic Kuusamo supracrustal belt and the Kemijärvi Complex, Central Fennoscandian Shield. IGCP-275/371 Symposium "Precambrian Crustal Evolution in the North Atlantic Regions", Nottingham, 13 - 17 Sept., 1994. Terra Nova 6, Abstract Supplement 2, p. 10.

Laajoki, K. 1996. Precambrian tempestite sequences in Finland. GFF 100 (Jubilee Issue), A106.

Laajoki, K. 2000. The Himmerkinlahti Member: an indicator of intra-Karelian erosion within the early Proterozoic Kuusamo Belt, Posio, northern Finland. Bulletin of the Geological Society of Finland 73, 71-85.

Ludwig, K.R. 1998. On the treatment of concordant uranium-lead ages. Geochimica et Cosmochimica Acta 62, 665-676.

Manninen, T. 1991. Sallan alueen vulkaniitit: Lapin vulkaniittiprojektin raportti. Summary: Volcanic rocks in the Salla area, northeastern Finland: A report of the Lapland Volcanite Project. Geological Survey of Finland, Report of Investigation 104. 97 p.

Pidgeon, R.T. 1992. Recrystallisation of oscillatory zoned zircon; some geochronological and petrological implications. Contributions to Mineralogy and Petrology 110, 463-472.

Ruotoistenmäki, T. 1992. Geophysical features indicating deep fractures in the Kuusamo area. In: Silvennoinen, A. (ed.) Deep fractures in the Paanajärvi-KuusamoKuolajärvi area: Proceedings of a Finnish-Soviet symposium in Finland on September 18-21, 1989. Geological Survey of Finland, Special Paper 13, 57-76.

Silvennoinen, A. 1972. On the stratigraphic and structural geology of the Rukatunturi area, northeastern Finland. Geological Survey of Finland, Bulletin 257. 48 p.

Silvennoinen, A. 1973. Kuusamo. Geological map of Finland 1 : 100 000, Pre-Quaternary rocks, sheet $4524+$ 4542. Geological Survey of Finland.

Silvennoinen, A. 1982. Rukatunturi. Geological map of Finland 1 : 100 000, Pre-Quaternary rocks, sheet 4613. Geological Survey of Finland.

Silvennoinen, A. 1989. Vasaraperä. Geological map of Finland $1: 100$ 000, Pre-Quaternary rocks, sheet 4522. Geological Survey of Finland.

Silvennoinen, A. 1991. Kuusamon ja Rukatunturin karttaalueiden kallioperä. Summary: Pre-Quaternary rocks of the Kuusamo and Rukatunturi map-sheet areas. Geological map of Finland 1: 1000 000, explanation to the maps of Pre-Quaternary rocks, sheets 4524+4542, 4613. 
Geological Survey of Finland. 62 p.

Silvennoinen, A. 1992. General geological setting and deep fracture structures in the Kuusamo-Kuolajärvi-Paanajärvi area. In: Silvennoinen, A. (ed.) Deep fractures in the Paanajärvi-Kuusamo-Kuolajärvi area : Proceedings of a Finnish-Soviet symposium in Finland on September 18-21, 1989. Geological Survey of Finland, Special Paper 13, 5-10.

Silvennoinen, A., Saltikova, T., Gaskelberg, L. \& Melezhik, V. 1992. Structural geological map over the Kuolajärvi (USSR) - Kuusamo (Finland) - Paanajärvi (USSR) area. In: Silvennoinen, A. (ed.) Deep fractures in the Paanajärvi-Kuusamo-Kuolajärvi area: Proceedings of a Finnish-Soviet symposium in Finland on September 18-21, 1989. Geological Survey of Finland, Special Paper 13, Appendix 1.

Stacey, J.S. \& Kramers, J.D. 1975. Approximation of terrestrial lead isotope evolution by a two-stage model. Earth and Planetary Science Letters 26, 207-221.

Vuollo, J. 1994. Palaeoproterozoic basic igneous events in the Eastern Fennoscandian Shield between 2.45 Ga and $1.97 \mathrm{Ga}$, studied by means of mafic dyke swarms and ophiolites in Finland. Acta Universitatis Ouluensis A 250. $116 \mathrm{p}$

Vuollo, J. \& Piirainen, T. 1992. The 2.2 Ga old Koli layered sill: The low-Al tholeiitic (karjalitic) magma type and its differentiation in northern Karelia, eastern Finland. Geologiska Föreningen i Stockholm, Förhandlingar 114, 131-142.

Weidenbeck, M., Allé, P., Corfu, F., Griffin, W.L., Meir, M., Oberli, F., von Quadt, A., Roddick, J.C. \& Spiegel, W. 1995. Three natural zircon standards for U-Th-Pb, Lu-Hf, trace element and REE analysis. Geostandards Newsletters 19, 1-23.

Whitehouse, M.J., Claesson, S., Sunde, T. \& Vestin, J. 1997. Ion microprobe U-Pb zircon geochronology and correlation of Archaean gneisses from the Lewisian Complex of Gruinard Bay, northwestern Scotland. Geochemica et Cosmochimica Acta 61, 4429-4438.

Whitehouse, M.J., Kamber, B.S. \& Moorbath, S. 1999. Age significance of U-Th-Pb zircon data from Early Archean rocks of West Greenland; a reassessment based on combined ion-microprobe and imaging studies. Chemical Geology 160, 201-224. 